\title{
Multiple sialolithiasis in submandibular gland duct: a rare case report
}

\author{
Sialolitíase múltipla em ducto de glândula \\ submandibular: um relato de caso raro
}

\author{
João Batista da SILVEIRA JUNIOR ${ }^{1}$ iD https://orcid.org/0000-0002-0733-560X \\ Joaquim Barbosa MATIAS NETO² iD https://orcid.org/0000-0002-1698-3414 \\ Ildeu ANDRADE JUNIOR ${ }^{1}$ iD https://orcid.org/0000-0002-2921-2627 \\ Herminia Marques CAPISTRANO² iD https://orcid.org/0000-0001-8546-0118
}

\section{ABSTRACT}

Sialolithiasis is a pathological process that affects the major salivary glands. It consists of calcifications that obstruct the parenchyma of the gland and / or the lumen of the ducts. The 37 years old female patient, VBB, leucoderma, attended the stomatology service with a complaint of swelling in the floor of mouth, which she noticed 10 years ago. The clinical and radiographic exams indicated a diagnosis of multiple sialolithiasis in the left submandibular gland duct. Surgical intervention was indicated in this case. Amongst all sialolithiasis cases, $80 \%$ affect the submandibular glands. Of these, $70 \%$ are isolated sialoliths. Only $5 \%$ of cases present more than 3 calcifications. This study aims to report the diagnosis and treatment of a rare case of multiple sialoliths located in the duct of the submandibular gland, which were surgically removed via intraoral access.

Indexing terms: Salivary glands. Submandibular gland. Salivary gland calculi.

\section{RESUMO}

Sialolitíase é um processo patológico que acomete as glândulas salivares maiores e consiste em calcificações que obstruem o parênquima da glândula elou a luz dos ductos. A paciente VBB do sexo feminino, leucoderma, 37 anos, compareceu ao serviço de estomatologia com a queixa de aumento de volume do assoalho bucal esquerdo iniciado a 10 anos. Com os exames clínicos e radiográficos fechou-se o diagnóstico de uma condição rara de sialolitíase múltipla no ducto da glândula submandibular esquerda com indicação de tratamento cirúrgico. $80 \%$ dos casos de sialolitíase acometem as glândulas submandibulares e $70 \%$ são cálculos únicos. Apenas 5\% dos casos apresentam mais de 3 calcificações. O presente trabalho tem como objetivo relatar um caso raro de sialolito múltiplo localizado no ducto da glândula submandibular e tratado através de remoção cirúrgica com acesso intraoral.

Termos de indexação: Glândulas salivares. Glândula submandibular. Cálculos das glândulas salivares.

$\boldsymbol{\nabla} \boldsymbol{\nabla} \nabla$

1 Pontifícia Universidade Católica de Minas Gerais - PUC Minas, Faculdade de Odontologia, Departamento de Ortodontia. Av. Dom José Gaspar, 500, Coração Eucarístico, 30535-901, Belo Horizonte, MG, Brasil. Correspondence to: JB Silveira Junior. E-mail: <juniorjbs@yahoo.com.br>.

2 Pontifícia Universidade Católica de Minas Gerais - PUC Minas, Faculdade de Odontologia, Departamento de Estomatologia. Belo Horizonte, MG, Brasil.

$\boldsymbol{\nabla} \mathbf{v}$

How to cite this article

Silveira Junior JB, Matias Neto JB, Andrade Junior I, Capistrano HM. Multiple sialolithiasis in submandibular gland duct: a rare case report. RGO, Rev Gaúch Odontol. 2020;68:e20200029. http://dx.doi.org/10.1590/1981-863720200002920180103 


\section{INTRODUCTION}

Sialolithiasis is a lesion of the salivary glands consisting of calcifications located in the glandular parenchyma or their associated ductal systems [1]. Intraductal sialoliths appear more commonly than those found in the glandular parenchyma [2]. Postmortem studies have shown that calculi are present in approximately $1.2 \%$ of the population and account for approximately $66 \%$ of all benign intraductal obstructions [1]. Autopsy reports suggest a prevalence between 1 and $2 \%$ and an incidence rates between 2.9 and 5.5 per 100,000 person-years [3].

A sialolith develops from a nucleus of mineralization around bacterial niches, debris, cell remnants, or foreign bodies $[4,5]$. Its etiology may be related to morpho-anatomical factors, salivary composition or its stasis. Increased salivary $\mathrm{pH}$, infections, inflammations, ductal or glandular trauma are factors that may predispose an individual to sialolithiasis $[2,5]$.

The calcifications found in the glandular ducts can present in various shapes and sizes $[5,6]$. When calculus affects the interior of the gland the mineralized masses are arranged as irregular agglomerates, requiring the excision of the gland as treatment [7].

80 to $90 \%$ of cases of sialolithiasis occur in the submandibular gland [7-10]. The most frequently affected age group is people between 30 and 40 years old. Males are affected twice as often as females $[5,9,10]$. Simultaneous findings in more than one salivary gland are uncommon, occurring in less than $3 \%$ of cases [9]. In $80 \%$ of cases, the disease presents as isolated calculi, and only $5 \%$ of patients have three or more sialoliths $[2,9]$.

Submandibular sialoliths located in the buccal floor can be detected by palpation $[2,4]$. Pain and edema at mealtimes or in response to other salivation stimuli are typical signs of calculus in the submandibular gland $[2,3,8,9,11]$. Clinical changes in sialolithiasis may remain asymptomatic when the obstruction of the saliva secretory pathways is partial $[1,11]$. The severity of pain and edema are associated with pressure and depend on the degree of obstruction of the affected gland [1], [9], [12].

\section{CASE REPORT}

VBB, a female patient, aged 37, leucoderma, attended the Stomatology Clinic of the Department of
Dentistry of the Pontifical Catholic University of Minas Gerais with complaints of increased left-ear floor volume and pain during mastication. The symptoms presented 10 years ago, however, the patient has only felt uncomfortable with the increased size of the nodule in the previous 7 months.

The patient's past medical history did not present any significant systemic alterations. During the general physical exame no edema, erythema or facial asymmetry were found. A submandibular ganglionar infarction on the left side was found during palpation, but did not produce changes in volume perceptible to visual exame. At the intraoral exame, an intramucosal volume increase similar to that of the oral mucosa and firm to palpation was observed, measuring approximately $25 \mathrm{~mm}$ in the region of the Wharton's duct of the left submandibular gland. The altered region had painful symptomatology during palpation. Salivary secretion was significantly reduced in the affected area.

Complementary imaging studies of the type of occlusal radiography of the mandible and panoramic radiography were performed to better visualize the lesion. The radiographs showed radiopaque bodies, suggesting a clinical diagnosis of multiple sialoliths in the duct of the submandibular gland.

The planned treatment was the surgical removal of the stones. An excisional biopsy was performed. After local anesthesia, an " $X$ " incision was made on the most anterior mucosa of the lesion, and dieresis of the duct with blunt scissors was performed. With the aid of a Lucas Curette, nine sialoliths were removed. The size of the stones ranged from less than about $1 \mathrm{~mm}$ to about $6 \mathrm{~mm}$. The surgery was performed with careful suturing, using $0.5 \mathrm{~mm}$ silk thread on the mucosa only, thus avoiding the closure of the duct. Sodium dipyrone 500mg administered orally was prescribed for three days for postoperative analgesia. At 15 days post-surgical intervention, at the time of suture removal, good resolution of the clinical picture was observed, with no patient complaints of pain and regression of the edema. After follow-up at 60 days, the patient did not present any evidence of relapse.

\section{DISCUSSION}

Sialolithiasis accounts for approximately $30 \%$ of salivary changes [2]. The submandibular gland is the most 


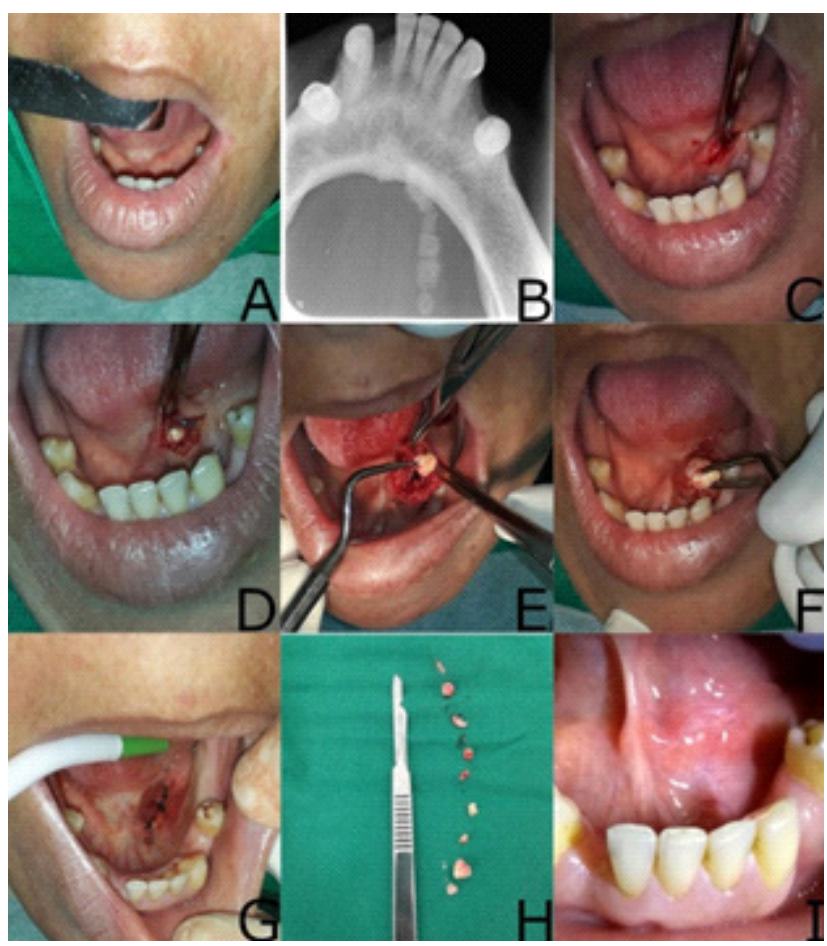

Figure 1. A. Aspect of the lesion in the preoperative period: an intra mucosal volume increase similar in color to that of the Oral mucosa; B. Occlusal radiograph showing multiple calculi; C-F. Initial incision, divulsion of tissues and removal of stones; G. Suture; H. 9 Removed Calculi with varying sizes; I. Appearance sublingual after 15 days.

susceptible to the development of calculi (80-95\%), and its duct is the most affected site. This susceptibility is due to the anatomical characteristics of the duct of the submandibular gland and the composition of its salivary secretion $[2,4,9]$. This case report corroborates these findings.

The literature describes a higher frequency of sialoliths in males and in individuals from 30-40 years of age, although they may also affect the young, the elderly, and in rare cases, children $[2,4,9,10]$. In this clinical case, the patient is female and was 39 years old.

The salivary calculi are usually unilateral and may be simple or multiple $[5,8,9]$. A unit calculus occurs in $75.3 \%$ of the cases, two sialoliths represent $15.6 \%$, and three represent $2.9 \%$ of cases. Findings with four to eight sialoliths represent $6.2 \%$ of cases $[6,7,9,11,13]$. In the present study, nine unilateral calculi were identified, representing a rare finding in the literature.

Salivary calculi vary widely in size and can be as small as $1 \mathrm{~mm}$ or may reach $10 \mathrm{~mm}$ (88\% of cases), as in the present case $[3,4,6]$. The mineral findings may be spindle-shaped, cylindrical, or spherical, and are yellowish- brown in color. Each of these formats can represent the traces of the location where the calculi were found. When found in the ducts, the calcification presents an elongated or cylindrical shape. When located inside the gland, the calcification usually has a round form $[2,11,14]$. The present study observed multiple sialoliths of various sizes, from less than $1.0 \mathrm{~mm}$ to $6.0 \mathrm{~mm}$, and in various forms.

The size of the sialolith can define its symptoms. Small calculi do not impede salivary flow and may be asymptomatic. It is noted that large or multiple stones result in an enlarged gland. The complaint of local sensation of tension and pain are characteristic signs of sialolithiasis, especially during meals, as described in the case reported here $[2,4,7,8,15]$.

The precise diagnosis of sialolithiasis is the product of a careful evaluation of the patient's history, typical symptoms presented, and findings of the clinical and imaging exams $[4,16,17]$. In most cases, clinical diagnosis is associated with conventional radiographic exames, but in special cases, it may be essential to use more-advanced exames such as computed tomography, sialography, ultrasonography, scintigraphy and magnetic resonance imaging to better locate and more accurately measure sialoliths for better surgical planning $[4,8,15,16]$. The use of radiography in the diagnosis of sialolithiasis is well recognized and has a good success rate $[1,10]$. An occlusal radiograph may reveal the calculi when it is located on the floor of the mouth, as was observed in the case described. Panoramic radiography can be used to evaluate calculi present in the glandular parenchyma [12]. Sialography is recommended for the identification of the calculus, when it is not radiographically visible [17]. In this case report, the general and special clinical exames associated with traditional radiographic exames (jaw occlusal and panoramic) presented sufficient data to conclude a clinical diagnosis.

Accurate diagnosis and immediate treatment of salivary calculi are essential for the restoration of proper glandular function. Treatment of the obstructive salivary phenomenon is closely related to the size of the stones. Very small sialoliths can be removed through patient hydration, glandular massage and using sialogogues. Thus, the increase in salivary production itself can expel sialoliths [15-18]. In cases of major or multiple sialolithiasis, the treatment of choice is surgical removal, as conducted in this case report. When the lesion involves the glandular parenchyma, there is a need for complete excision of the gland [6], [8], [9], [10]. Surgical treatment of sialolithiasis, with an intrabuccal approach, rarely presents postoperative 
complications. However, when complications occur, the most common are duct stenosis, fibrosis in the duct area, and formation of a saliva retention phenomenon $[7,10,15]$.

Good diagnostic procedures, correct ductal dissection, and careful suturing minimize the appearance of complications in the postoperative period, as occurred in the case report presented here $[16,18,19]$.

\section{CONCLUSION}

Correct clinical and imaging diagnosis are key components in the treatment of multiple submandibular sialolithiasis. Years of discomfort generated by a rare case of sialolithiasis were eliminated with a simple outpatient surgery technique, returning the quality of life to the patient.

\section{Collaborators}

JB SILVEIRA JUNIOR, main writer and surgeon responsible for patient's referral and clinical follow-up. JB MATIAS NETO, assistant editor of the article and first surgeon of the case. I ANDRADE JUNIOR, didactic orientation of the case and technical reviewer of the article. HM CAPISTRANO, clinical orientation of the case and technical reviewer of the article.

\section{REFERENCES}

1. Lee LI, Pawar RR, Whitley S, Makdissi J. Incidence of different causes of benign obstruction of the salivary glands: retrospective analysis of 493 cases using fluoroscopy and digital subtraction sialography. $\mathrm{Br} J$ Oral Maxillofac Surg. 2015;53(1):54-7. DOI: 10.1016/j.bjoms.2014.09.017.

2. Sigismund PE, Zenk J, Koch M, Schapher M, Rudes M, Iro H. Nearly 3,000 salivary stones: some clinical and epidemiologic aspects. Laryngoscope. 2015;125(8):1879-82. DOI: 10.1002/ lary. 25377.

3. Schrøder SA, Andersson M, Wohlfahrt J, Wagner N, Bardow A, Homøe P. Incidence of sialolithiasis in Denmark: a nationwide population-based register study. Eur Arch Otorhinolaryngol. 2017;274(4):1975-81. DOI: 10.1007/s00405-016-4437-z.

4. Veniaminivna Kolomiiets $S$, Oleksandrivna Udaltsova $K$, Andriivna Khmil T, Mykolaiivna Yelinska A, Anatoliivna Pisarenko O, Ihorivna Shynkevych V. Difficulties in Diagnosis of Sialolithiasis: A Case Series. Bull Tokyo Dent Coll. 2018;59(1):53-8. http://dx.doi.org/10.2209/tdcpublication. 2017-0013

5. Jáuregui E, Kiringoda R, Ryan WR, Eisele DW, Chang JL. Chronic parotitis with multiple calcifications: Clinical and sialendoscopic findings. Laryngoscope. 2017;127(7):1565-70.
6. Demircan S, Ișler S. Case reports: Giant sialolith. Br Dent J. 2015;219(2):48. http://dx.doi.org/10.1038/sj.bdj.2015.583

7. Foletti JM, Graillon N, Avignon S, Guyot L, Chossegros C. Salivary Calculi Removal by Minimally Invasive Techniques: A Decision Tree Based on the Diameter of the Calculi and Their Position in the Excretory Duct. J Oral Maxillofac Surg. 2018;76(1):112-8. http://dx.doi.org/10.1016/j.joms.2017. 06.009

8. Krishnappa BD. Multiple submandibular duct (Wharton's duct) calculi of unusual size and shape. Indian J Otolaryngol Head Neck Surg.2010;62(1):88-9. http://dx.doi.org/10.1007/ s12070-010-0018-4

9. Sunder VS, Chakravarthy C, Mikkilinine R, Mahoorkar S. Multiple bilateral submandibular gland sialolithiasis. Niger J Clin Pract. 2014;17(1):115-8. DOI: 10.4103/1119-3077.122870.

10. Choi J, Kim IK, Oh NS. Multiple sialoliths in sublingual gland: report of a case. Int J Oral Maxillofac Surg. 2002;31:562-3. http://dx.doi.org/10.12659/AJCR.882599.

11. Lee KC, Ferguson BM. Intermittent Pain with Meals. J Emerg Med. 2018;55(3):e79-e80. http://dx.doi.org/10.1016/j. jemermed.2018.05.033

12. Sobrino-Guijarro B, Cascarini L, Lingam RK. Advances in imaging of obstructed salivary glands can improve diagnostic outcomes. Oral Maxillofac Surg. 2013;17(1):11-9. http:// dx.doi.org/10.1007/s10006-012-0327-8

13. Cho W, Lim D, Park H. Transoral sonographic diagnosis of submandibular duct calculi. J Clin Ultrasound. 2014;42(2):125-8. http://dx.doi.org/10.1002/jcu.22063

14. Xiao JQ, Sun HJ, Qiao QH, Bao X, Wu CB, Zhou Q. Evaluation of Sialendoscopy-Assisted Treatment of Submandibular Gland Stones. J Oral Maxillofac Surg. 2017;75(2):309-16. http:// dx.doi.org/10.1002/jcu.22063

15. Aubin-Pouliot A, Delagnes EA, Chang JL, Ryan WR. Sialendoscopy-assisted surgery and the chronic obstructive sialadenitis symptoms questionnaire: A prospective study. Laryngoscope. 2016;126(6):1343-8. http://dx.doi.org/10.10 02/lary.25759

16. Schwarz D, Kabbasch C, Scheer M, Mikolajczak S, Beutner D, Luers JC. Comparative analysis of sialendoscopy, sonography, and $C B C T$ in the detection of sialolithiasis. Laryngoscope. 2015;125(5):1098-101. http://dx.doi.org/10.1002/lary.24966

17. Schwartz N, Hazkani I, Goshen S. Combined approach sialendoscopy for management of submandibular gland sialolithiasis. Am J Otolaryngol. 2015;36(5):632-5. http://dx.doi. org/10.1016/j.amjoto.2015.04.001

18. Gillespie MB, O'Connell BP, Rawl JW, McLaughlin CW, Carroll WW, Nguyen SA. Clinical and quality-of-life outcomes following gland-preserving surgery for chronic sialadenitis. Laryngoscope. 2015;125(6):1340-4. http://dx.doi.org/10.10 02/lary. 25062

19. Gerni M, Foletti JM, Collet C, Chossegros C. Evaluation of the prevalence of residual sialolith fragments after transoral approach of Wharton's duct. J Craniomaxillofac Surg. 2017;45(2):167-70. http://dx.doi.org/10.1016/j.jcms.2016.04.011

Received on: 26/12/2018

Final version resubmitted on: 18/3/2019

Approved on: 17/5/2019 